\title{
DOES FISCAL DECENTRALIZATION INCREASES REGIONAL INCOME INEQUALITY IN INDONESIA?
}

\author{
Afief El Ashfahany ${ }^{1}$, Rifi Fazrina Djuuna ${ }^{2}$, Nur Fahmi Rofiq ${ }^{3}$ \\ ${ }^{1}$ International Centre for Education in Islamic Finance, INCEIF, Kuala Lumpur, \\ Malaysia \\ ${ }^{2}$ Department of Economic Development, Faculty of Economics, Gorontalo State \\ University, Indonesia \\ ${ }^{3}$ Directorate General of Chemical, Pharmacy, and Textile, Ministry of Industry, \\ Indonesia
}

\begin{abstract}
This paper examines the impact of fiscal decentralization on regional income inequality in Indonesia. This study employs dynamic panel data analysisthe two-step system generalized method of moments (GMM) on 2008-2017 regional level datasets. This study found that regional income inequality indeed increases during the implementation of fiscal decentralization and appears to be exceptionally high for rich provinces. Essentially, this study suggest that fiscal decentralization appears to increase regional income inequality in Indonesia. The results might be due to low regional fiscal capacity in Indonesia, which induces high dependency of local government that further restraints local competition in public goods provision.
\end{abstract}

Keywords: fiscal decentralization, regional income inequality, generalized method of moments (GMM).

\section{INTRODUCTION}

Fundamental purpose behind Indonesia's economic reform was to improve economic performance in view of the failure of centralized government system. Such failure arises due to the issue of increasing regional income inequality between urban and rural areas in Indonesia
(Booth, 1998) and the issue of local government's immense dependency on national government. To resolve the issues, Indonesia implemented decentralized government system, which substantially changed Indonesia's economic and political views to regional autonomy. Decentralization highlights the 
specific role of regional government in managing administrative, political, and fiscal resources. Consequently, Indonesia implemented fiscal decentralization system by utilizing intergovernmental transfer as balance funds. Indonesia's balance funds consisted of general allocation funds (dana alokasi umum/DAU), revenue sharing funds (dana bagi hasil/DBH), and special allocation funds (dana alokasi khusus/DAK).

Accordingly, further question arises to what extend would fiscal decentralization resolve the issue of regional income inequality in Indonesia. Despite growing literature regarding the issue, the results remain inconclusive. Dyah (2012), Hartono \& Irawan (2011), Siddique et al., 2008) concluded that fiscal decentralization appears to increase inequality in Indonesia, while Setiawan \& Aritenang (2019) and Siburian (2019) found that inequality tends to decrease due to the implementation of fiscal decentralization. Therefore, the impact of fiscal decentralization on income inequality needs to be addressed further to find conclusive results.

Thus, this study aims to investigate the impact of fiscal decentralization on regional income inequality. This study uses panel datasets from 33 provinces in Indonesia during 2008-2017. Furthermore, this study explores local government's expenditure as main proxy to the implementation of fiscal decentralization in Indonesia. The remainder of the paper is structured as follows: the next section reviews existing literature on fiscal decentralization and inequality, section 3 provides methodology and econometric strategy used in the paper, followed with results and discussion, lastly, the final section draws conclusions of this study.

\section{LITERATURE REVIEW}

Previous studies have investigated the relationship between fiscal decentralization and inequality. Studies concluded that fiscal decentralization may reduce inequality under specific condition. Goerl \& Seiferling (2014), Setiawan \& Aritenang (2019), and Sepulveda \& 
Martinez-Vazquez (2011) suggested that government size, independence, and development level may contribute in reducing inequality amid fiscal decentralization. Goerl \& Seiferling (2014) found that independency towards regional revenue and intergovernmental transfer may boost economic performance and redistribute spending that will further reduce inequality. Sepulveda \& MartinezVazquez (2011) concluded that government's size on budget may decrease inequality. Setiawan \& Aritenang (2019) highlighted that efficient fiscal decentralization may boost economic performance and further reduce inequality.

On the contrary, studies of Dyah (2012) and Siddique et al. (2008) concluded that fiscal decentralization increases inequality. Inequal regional income is further acknowledged as major disadvantage of fiscal decentralization. Potentially, local government's capability and other social-economic factors may contribute in increasing inequality. Dyah (2012) concluded that intergovernmental transfer only prospers rich region. Siddique et al. (2008) found that fiscal decentralization degree is considerably low in Indonesia that local government lacks independence towards local revenue and intergovernmental transfer, therefore increasing inequality is inevitable. Additionally, Liu et al. (2017) found that fiscal decentralization tend to increase inequality due to variability of level of economic development, inequal regional distributive policies, natural resources, and infrastructure imbalance. Therefore, fiscal decentralization may widen the gap between the rich and poor region that further increases inequality.

Discussions of existing literature on fiscal decentralization in Indonesia remains inconclusive. Some argue that fiscal decentralization boosts economic performance and decreases inequality (Siburian, 2019; Setiawan \& Aritenang, 2019), while other studies suggests that fiscal decentralization may worsen inequality (Aji, 2020; Dyah, 2012; Djuuna \& Widodo, 2016; Hartono \& Irawan, 2011; Siddique et al., 2008). In favour to 
fiscal decentralization, Siburian (2019) found that intergovernmental transfer mitigated inequality in Indonesia through efficient local government's competition in public goods provision. On the contrary, Siddique et al. (2008) conclude that fiscal decentralization worsen inequality in Indonesia due to limited resource endowments, low level of economic development, regional imbalances, and inefficient intergovernmental transfer practices. Aji (2020) further verify that regional imbalance on human capital development and infrastructure essentially widen the gap between rich and poor region in Indonesia.

Majority of the studies that were discussed in the literature review used different approaches in measuring fiscal decentralization and regional income inequality. Siburian (2019) applied Simultaneous Equation Model (SEM) on provincial level data in Indonesia while exploring expenditure side of fiscal decentralization in Indonesia. Hartono \& Irawan (2011) developed Theil indices on country and province level which further highlights within- between sector income inequality. While studies of Djuuna \& Widodo, (2016) and Siddique et al. (2008) used enhancement fiscal decentralization indices that apprehend expenditure and revenue side of decentralization in Indonesia which portrays provincial and regional own source revenue, intergovernmental transfer, and the adjustment coefficient of conditional and non-conditional transfers.

Essentially, different methods and approaches developed in existing literature in Indonesia result in inconclusive result. Remarkably, we found that studies of Setiawan \& Aritenang (2019) and Siburian (2019) disregard spatial dependency withinbetween region in Indonesia, which probably derived contradictory findings in existing literature. In the interest of the issue in Indonesia, we argue that spatial dependence and regional imbalances play significant role in defining fiscal decentralization in Indonesia.

Therefore, this study attempts to estimate the association between fiscal decentralization and regional income inequality by incorporating 
the issue regional imbalances in Indonesia. We are also motivated by the complexity of decentralization indices in Djuuna \& Widodo (2016) and Siddique et al. (2008), we attempt to focus on expenditure side of fiscal decentralization in Indonesia as focal point of this study.

\section{METHODOLOGY}

This study aims to investigate the impact of fiscal decentralization on regional inequality in Indonesia. Generally, this study includes 20082017 regional level datasets of regional government expenditure, intergovernmental transfer, and gross regional domestic product (GRDP) as the main independent and dependent variable. The datasets were obtained from Directorate General of Fiscal Balance, Ministry of Finance, Central Bureau of Statistics, and Indonesia Database for Policy and Economic Research (INDO-DAPOER) World Bank.

To implement analysis in investigating the issue, this study requires panel data analysis. To estimate fiscal decentralization, we use spending decentralization measure in measuring fiscal decentralization degree in Indonesia. Fiscal decentralization in Indonesia emphasized the significance of intergovernmental transfer to local governments in arranging spending priorities to fulfil regional preference on public goods provision. Following Lessmann (2009) and Siburian (2019), we define spending decentralization as ratio of local government spending on national government spending. Moreover, we mainly use Williamson Index in measuring regional inequality in Indonesia. Furthermore, we use several control variables, such as household expenditure per capita, years of schooling, life expectancy, and government size.

Summary of variables in the models are further described in Table 1. Main independent variable is the provincial level of regional inequality in Indonesia. This study measure municipality and district level datasets of GRDP as a proxy to provincial inequality in all provinces in Indonesia. The estimation of regional inequality was based on 
Williamson (1965). The equation is as follows:

$$
V W=\frac{\sqrt{\sum_{i=1}^{n}\left(y_{i}-\bar{y}\right)^{2}\left(\frac{f_{i}}{n}\right)}}{\bar{y}} \ldots \ldots(\text { Eq.1) }
$$

where $y_{i}, \bar{y}, f_{i}$ are the GRDP per capita, mean of GRDP per capita, population share of province $i$ respectively, while $n$ is the number of regions.

Table 1. Summary of Variables

\begin{tabular}{llcl}
\hline Variable & Indicator & Notation & Data Source \\
\hline $\begin{array}{l}\text { Regional } \\
\text { Inequality }\end{array}$ & Williamson Index & VW & $\begin{array}{l}\text { Central Bureau of Statistics and } \\
\text { INDO-DAPOER, World Bank }\end{array}$ \\
\hline $\begin{array}{l}\text { Fiscal } \\
\text { Decentralization }\end{array}$ & $\begin{array}{l}\text { Spending decentralization; } \\
\text { ratio of local government's } \\
\text { expenditure on overall } \\
\text { national government's } \\
\text { expenditure }\end{array}$ & FDI & $\begin{array}{l}\text { Directorate of Fiscal Balance, } \\
\text { Ministry of Finance }\end{array}$ \\
\hline $\begin{array}{l}\text { Household } \\
\begin{array}{l}\text { Expenditure per } \\
\text { Capita }\end{array}\end{array}$ & HOUSEXP & $\begin{array}{l}\text { Central Bureau of Statistics and } \\
\text { INDO-DAPOER, World Bank }\end{array}$ \\
\hline Education & Mean years of schooling & MYS & Central Bureau of Statistics \\
\hline $\begin{array}{l}\text { Health } \\
\text { Sovernment }\end{array}$ & $\begin{array}{l}\text { Rife expectancy rate } \\
\text { Ratio of local government's }\end{array}$ & GHH & Central Bureau of Statistics \\
\hline
\end{tabular}

Source: Central Bureau of Statistics, Directorate of Fiscal Balance, Ministry of Finance, INDODAPOER, World Bank, 2004-2017.

To summarize, this study uses provincial level datasets derived from regional level datasets of government expenditure, intergovernmental transfer, and GRDP in Indonesia. This study further employs ordinary least square (OLS) panel data analysis in investigating the impact of fiscal decentralization on regional income inequality.

$$
\text { However, preliminary }
$$
explorations indicated that datasets were not distributed normally and potentially suffers serial autocorrelation and the issue of heteroskedasticity that would result in biased OLS estimates. To avoid reverse causation due to the issue of serial autocorrelation, this study further implements dynamic panel data analysis following Siddique et al. (2008) and Djuuna \& Widodo (2016) and further consider the impact of lagged inequality coefficient in the explanatory variables. To accommodate the issue, this study 
uses generalised method of moments (GMM) developed by Arellano \& Bond (1991) ${ }^{1}$. Therefore, the impact of fiscal decentralization on inequality in Indonesia is investigated by employing the following model, as follows:

$$
\begin{gathered}
\mathrm{VW}_{\mathrm{i}, \mathrm{t}}=\alpha \mathrm{VW}_{\mathrm{i}, \mathrm{t}-1}+\beta \mathrm{FDI}_{\mathrm{i}, \mathrm{t}}+\sum \gamma_{\mathrm{k}} \mathrm{X}_{\mathrm{i}, \mathrm{t}, \mathrm{k}}+ \\
\mathrm{v}_{\mathrm{i}}+\varepsilon_{\mathrm{i}, \mathrm{t}} \ldots \ldots \text { (Eq.2) }
\end{gathered}
$$

where $\mathrm{VW}_{\mathrm{i}, \mathrm{t}}$ is the Williamson Index of province $i$ at time $t ; \mathrm{VW}_{\mathrm{i}, \mathrm{t}-1}$ is a lag of the Williamson index of province $i ; \mathrm{FDI}_{\mathrm{i}, \mathrm{t}}$ is the spending decentralization index; $\alpha$ is the regression coefficient of the lag of Williamson Index; $\beta$ is the regression coefficient of FDI; $\gamma_{k}$ are the regression coefficients of control variables $X_{i, t, k} ; v_{i}$ is the fixed effect, and $\varepsilon_{\mathrm{i}, \mathrm{t}}$ is the error term.

\section{RESULTS AND DISCUSSION}

Increasing regional income inequality is evident during implementation of fiscal decentralization in Indonesia. The result of Williamson Index analysis is summarized in Table 2.

1 This study specifically uses xtabond2 command in STATA developed by (Roodman, 2006). This study also compares
Despite fluctuations, the result shows that the increase of regional income inequality is inevitable during the period of 2008-2017. According to the result, inequality appears to be higher for rich region, such as DKI Jakarta, East Java, Papua, Banten, North Sumatera, Central Java, Riau, and East Kalimantan.

Taking fiscal decentralization into account, this study shows that fiscal decentralization degree in Indonesia is relatively low, as it is summarized in Figure 1. This result suggests that local government practically relies on national government in financing needs. Lower degree of fiscal decentralization induces inefficiency of local government due to budget constraints and overinvestment issues in public goods provision (Bellofatto \& Besfamille, 2018).

To strengthen the argument, we specifically measure Indonesia's fiscal capacity which is summarized in Figure 2.

first difference GMM and system GMM results to avoid biased coefficient estimates. 
Table 2. Regional Income Inequality in Indonesia ${ }^{2}$

\begin{tabular}{|c|c|c|c|c|c|c|c|c|c|c|}
\hline Province & 2008 & 2009 & 2010 & 2011 & 2012 & 2013 & 2014 & 2015 & 2016 & 2017 \\
\hline Aceh & 0.40 & 0.41 & 0.45 & 0.46 & 0.48 & 0.52 & 0.51 & 0.50 & 0.53 & 0.53 \\
\hline North Sumatera & 0.55 & 0.65 & 0.66 & 0.66 & 0.72 & 0.73 & 0.71 & 0.71 & 0.70 & 0.49 \\
\hline West Sumatera & 0.37 & 0.37 & 0.35 & 0.34 & 0.33 & 0.31 & 0.35 & 0.34 & 0.34 & 0.35 \\
\hline Jambi & 0.26 & 0.26 & 0.24 & 0.25 & 0.23 & 0.24 & 0.28 & 0.27 & 0.27 & 0.26 \\
\hline Riau & 0.31 & 0.30 & 0.30 & 0.31 & 0.33 & 0.32 & 0.36 & 0.37 & 0.37 & 0.38 \\
\hline Kepulauan Riau & 0.51 & 0.51 & 0.49 & 0.48 & 0.48 & 0.45 & 0.38 & 0.38 & 0.38 & 0.37 \\
\hline Bengkulu & 0.41 & 0.40 & 0.40 & 0.40 & 0.40 & 0.41 & 0.41 & 0.41 & 0.40 & 0.40 \\
\hline South Sumatera & 0.39 & 0.38 & 0.39 & 0.39 & 0.40 & 0.41 & 0.40 & 0.39 & 0.39 & 0.39 \\
\hline Bangka Belitung & 0.31 & 0.31 & 0.31 & 0.30 & 0.34 & 0.36 & 0.35 & 0.35 & 0.34 & 0.34 \\
\hline Lampung & 0.27 & 0.26 & 0.28 & 0.30 & 0.34 & 0.36 & 0.36 & 0.36 & 0.36 & 0.36 \\
\hline DKI Jakarta & 0.56 & 0.54 & 0.55 & 0.53 & 0.51 & 0.54 & 0.60 & 0.59 & 0.60 & 0.61 \\
\hline West Java & 0.62 & 0.62 & 0.62 & 0.60 & 0.59 & 0.58 & 0.56 & 0.54 & 0.52 & 0.54 \\
\hline Banten & 0.81 & 0.81 & 0.81 & 0.83 & 0.80 & 0.76 & 0.77 & 0.77 & 0.77 & 0.77 \\
\hline Central Java & 0.74 & 0.74 & 0.71 & 0.71 & 0.71 & 0.70 & 0.70 & 0.67 & 0.66 & 0.66 \\
\hline DI Yogyakarta & 0.42 & 0.43 & 0.44 & 0.44 & 0.44 & 0.44 & 0.46 & 0.45 & 0.45 & 0.46 \\
\hline East Java & 0.97 & 0.97 & 0.98 & 0.98 & 0.98 & 0.98 & 1.11 & 1.16 & 1.17 & 1.18 \\
\hline Bali & 0.40 & 0.39 & 0.39 & 0.39 & 0.40 & 0.43 & 0.43 & 0.43 & 0.43 & 0.43 \\
\hline West Nusa Tenggara & 0.36 & 0.39 & 0.41 & 0.43 & 0.43 & 0.44 & 0.44 & 0.44 & 0.44 & 0.42 \\
\hline East Nusa Tenggara & 0.50 & 0.51 & 0.56 & 0.49 & 0.44 & 0.45 & 0.45 & 0.44 & 0.45 & 0.44 \\
\hline West Kalimantan & 0.33 & 0.33 & 0.32 & 0.32 & 0.32 & 0.32 & 0.29 & 0.28 & 0.28 & 0.28 \\
\hline Central Kalimantan & 0.27 & 0.26 & 0.26 & 0.23 & 0.21 & 0.21 & 0.21 & 0.20 & 0.20 & 0.20 \\
\hline South Kalimantan & 0.44 & 0.43 & 0.43 & 0.43 & 0.43 & 0.43 & 0.42 & 0.42 & 0.42 & 0.42 \\
\hline East Kalimantan & 0.47 & 0.48 & 0.56 & 0.55 & 0.60 & 0.61 & 0.62 & 0.62 & 0.67 & 0.67 \\
\hline North Sulawesi & 0.37 & 0.37 & 0.38 & 0.38 & 0.38 & 0.40 & 0.40 & 0.41 & 0.41 & 0.41 \\
\hline Gorontalo & 0.23 & 0.23 & 0.23 & 0.24 & 0.21 & 0.19 & 0.19 & 0.19 & 0.19 & 0.19 \\
\hline Central Sulawesi & 0.22 & 0.23 & 0.24 & 0.25 & 0.26 & 0.27 & 0.27 & 0.27 & 0.27 & 0.27 \\
\hline South Sulawesi & 0.62 & 0.62 & 0.61 & 0.61 & 0.58 & 0.53 & 0.51 & 0.51 & 0.51 & 0.51 \\
\hline Southeast Sulawesi & 0.39 & 0.39 & 0.40 & 0.42 & 0.39 & 0.35 & 0.35 & 0.35 & 0.35 & 0.32 \\
\hline West Sulawesi & 0.19 & 0.16 & 0.14 & 0.16 & 0.16 & 0.14 & 0.14 & 0.13 & 0.14 & 0.14 \\
\hline Maluku & 0.57 & 0.57 & 0.58 & 0.58 & 0.57 & 0.56 & 0.56 & 0.56 & 0.55 & 0.55 \\
\hline North Maluku & 0.28 & 0.27 & 0.26 & 0.26 & 0.26 & 0.29 & 0.30 & 0.29 & 0.30 & 0.30 \\
\hline Papua & 2.79 & 2.88 & 2.98 & 3.02 & 2.99 & 3.54 & 3.62 & 3.59 & 3.57 & 3.51 \\
\hline West Papua & 0.21 & 0.21 & 0.22 & 0.21 & 0.21 & 0.21 & 0.21 & 0.22 & 0.22 & 0.23 \\
\hline
\end{tabular}

Source: own calculation

${ }^{2}$ Regional income inequality is measured with Williamson Index. Provincial regional income inequality is derived from municipality and district level datasets of GRDP from Central Bureau of Statistics 
Does Fiscal Decentralization Increases Regional Income Inequality in Indonesia?

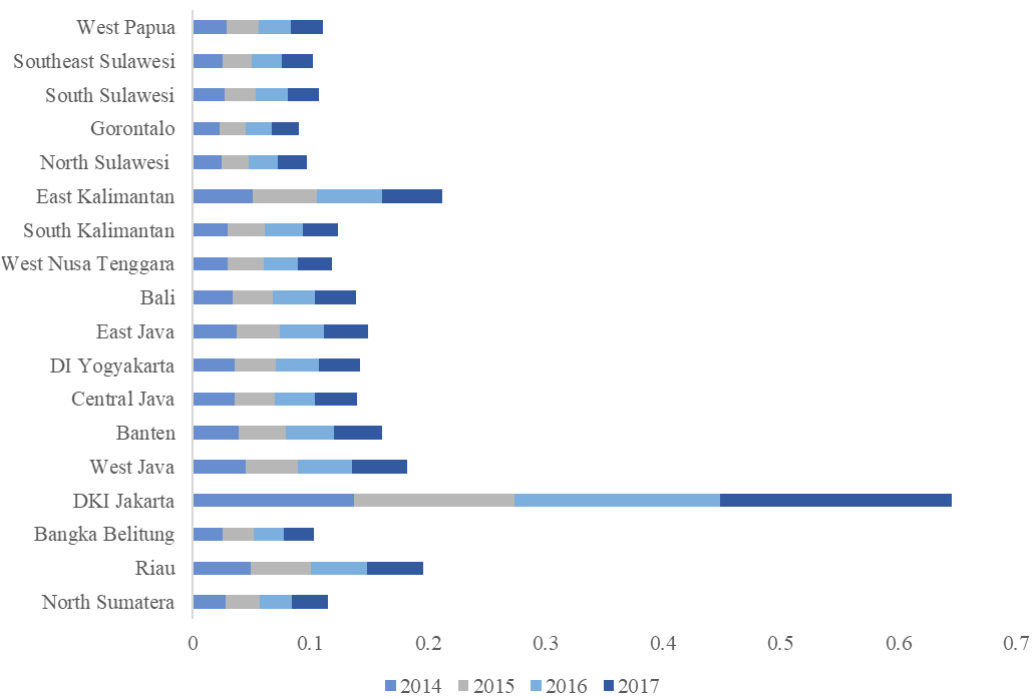

Figure 1. Degree of Fiscal Decentralization in Indonesia Source: Own calculation

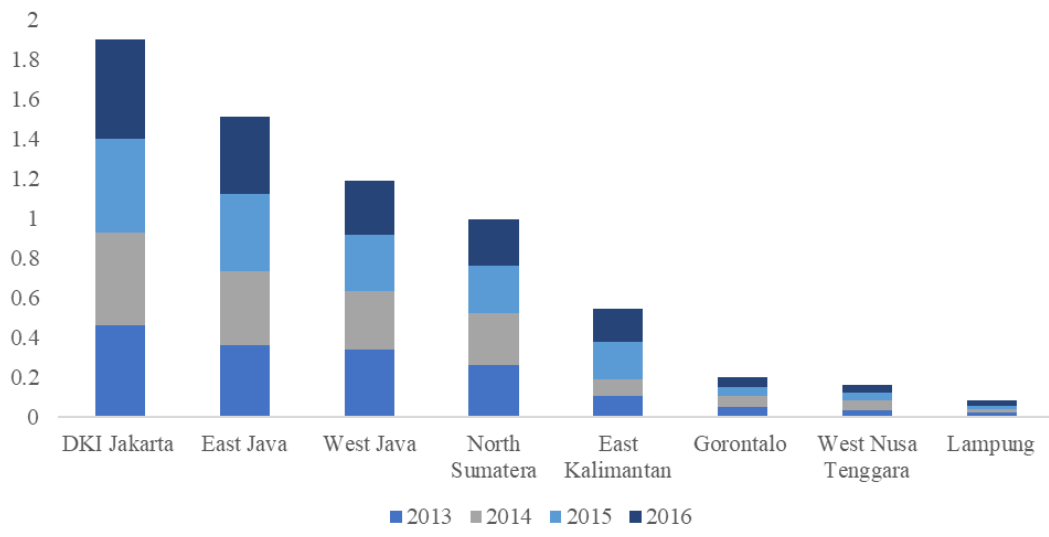

Figure 2. Regional Fiscal Autonomy (Selected Provinces in Indonesia) Source: Own calculation

Figure 2 suggests that fiscal capacity $^{3}$ varies in each province in Indonesia. It is evident that fiscal capacity appears to be higher for rich region. Figure 2 shows that rich provinces such as DKI Jakarta, East Java, North Sumatera, and West Java has higher level of fiscal capacity, while other region appears to have lower level of fiscal capacity.

This finding implies that most region in Indonesia depends on the national government in terms of expenditure and financing needs. Thus, proves that local government relies on intergovernmental transfer in public goods provision.

\footnotetext{
${ }^{3}$ Fiscal capacity is measured as the ratio of provincial Own Source Revenue relative to the provincial Government Expenditure.
} 
Table 2 presents econometric results that estimates the impact of fiscal decentralization on regional income inequality in Indonesia. Column 1 and Column 2 presents OLS results on the estimate, Column 3 presents first-difference GMM results, Column 4 and Column 5 presents one-step system GMM and two-step system GMM respectively. As discussed in the previous section, preliminary explorations indicated that the datasets were not distributed normally and suffers serial autocorrelation and the issue of heteroskedasticity that results in biased OLS coefficient estimates as it is evident in Table 2.

Table 2. Impact of Fiscal Decentralization on Regional Income Inequality

\begin{tabular}{cccccc}
\hline & $(1)$ & $(2)$ & $(3)$ & $(4)$ & $(5)$ \\
\hline VW (-1) & & & $0.075^{* *}$ & $0.988^{* * *}$ & $0.877^{* * *}$ \\
& & & $(0.002)$ & $(0.028)$ & $(0.007)$ \\
\hline FDI & -0.013 & $-0.004^{*}$ & 0.004 & 0.180 & $0.213^{* *}$ \\
& $(0.001)$ & $(0.013)$ & $(0.013)$ & $(0.098)$ & $(0.013)$ \\
\hline HOUSEXP & -0.001 & -0.002 & $-0.002^{*}$ & -0.007 & $-0.022^{* *}$ \\
& $(0.013)$ & $(0.010)$ & $(0.012)$ & $(0.134)$ & $(0.010)$ \\
\hline MYS & 0.033 & 0.064 & -0.550 & -0.013 & $0.194 * *$ \\
& $(0.010)$ & $(0.001)$ & $(0.001)$ & $(0.024)$ & $(0.001)$ \\
\hline AHH & -0.091 & -0.146 & -0.102 & 0.003 & -0.025 \\
& $(0.001)$ & $(0.003)$ & $(0.001)$ & $(0.004)$ & $(0.004)$ \\
\hline GOV & & -0.006 & 0.025 & -0.032 & $-0.020 *$ \\
& & $(0.003)$ & $(0.018)$ & $(0.180)$ & $(0.020)$ \\
\hline AR $(2)$ & - & - & 0.13 & 0.81 & 0.16 \\
\hline Adj. $R^{2}$ & 0.0010 & 0.0232 & - & - & - \\
\hline Observation & 297 & 297 & 297 & 297 & 297 \\
\hline
\end{tabular}

Note: The estimate uses 2008-2017 provincial level datasets in Indonesia. The dependent variable is regional income inequality index on all column. All regressions include a constant. All regressions are robust in standard errors. Standard errors in parenthesis. ${ }^{* * *}, *^{* * *}$ : significant at $1 \%, 5 \%$, and $10 \%$. Source: Own calculation

This study further focuses on two-step system GMM results as the model potentially resolved the issue of serial autocorrelation, invalid instrument,

\footnotetext{
${ }^{4}$ The AR(2) and Sargan Test proved that twostep system GMM resolved the issue of serial correlation and invalid instruments.
}

and appears to generate unbiased estimates ${ }^{4}$.

Main finding of this study shows that fiscal decentralization appears to increase regional income 
inequality in Indonesia. This result suggests that an increase of FDI by 1 unit leads to the increase of regional income inequality by 0.21 units. This result essentially highlights the issue of low degree of fiscal decentralization and fiscal autonomy in Indonesia, considering fiscal decentralization only appears to be beneficial for rich region. Hence, results in local government's dependency on national government. Local government's dependency on intergovernmental transfer system also results in the restraint of interregion competition between local governments in public goods provision, which proves the inefficiency of fiscal decentralization in Indonesia. This result is in line with studies of Dyah (2012), Liu et al. (2017), Qiao et al. (2008), Siddique et al. (2008), and Stossberg \& Blöchliger (2017).

Finally, the result of the study also confirms that controlled variables such as household expenditure per capita, education, and government's size are associated with fiscal decentralization. Table 2 shows that higher degree of education leads to larger regional income inequality, while higher government size leads to the reduce of regional income inequality.

\section{CONCLUSION}

This study investigates the impact of fiscal decentralization on regional income inequality in Indonesia. Main findings in the study concluded that fiscal decentralization increases regional income inequality. This study further suggests that fiscal decentralization and fiscal capacity in Indonesia is relatively low and fiscal decentralization only appears to be beneficial for rich region. Lower fiscal capacity induces local government's dependency on intergovernmental transfer system that further results in inefficient public goods provision and restraints inter-region competition in Indonesia.

Remarks from this study needs to be addressed with further research due to some limitations. First, this study mainly uses regional government's total expenditure as focal point without considering differences on regional policies regarding expenditure allocation. 
Secondly, this study focuses mainly on the economic point of view of decentralization without considering political, social, and administrative aspect of regional autonomy. Lastly, this study employs basic econometric model due to limited source of datasets.

\section{REFERENCES}

Aji, W. M. (2020). Spatial Dimensions of Economic Growth, Redistribution, and Poverty Reduction During the Yudhoyono Period in Indonesia. Jambura Equilibrium Journal, 2(1).

https://doi.org/10.37479/jej.v2i1 .4498

Arellano, M., \& Bond, S. (1991). Some Tests of Specification for Panel Data: Monte Carlo Evidence and an Application to Employment Equations. The Review of Economic Studies, 58(2), 277. https://doi.org/10.2307/2297968

Bellofatto, A. A., \& Besfamille, M. (2018). Regional state capacity and the optimal degree of fiscal decentralization. Journal of Public Economics, 159(2018), 225-243.

https://doi.org/10.1016/j.jpubec o.2017.12.010

Booth, A. (1998). The Indonesian Economy in the Nineteenth and Twentieth Centuries. In The
Indonesian Economy in the Nineteenth and Twentieth Centuries.

https://doi.org/10.1057/9780333 994962

Djuuna, R. F., \& Widodo, W. (2016). Desentralisasi Fiskal dan Ketimpangan Regional di Indonesia tahun 2004 - 2013. Undergraduate Thesis Faculty of Economics and Business Diponegoro University. http://eprints.undip.ac.id/51448/

Dyah, S. M. (2012). The Impact of Fiscal Decentralization on Corruption in Indonesia. Jurnal Borneo Administrator, 8(3), 293-309. http://samarinda.lan.go.id/jba/in dex.php/jba/article/view

Goerl, C.-A., \& Seiferling, M. (2014). Income Inequality, Fiscal Decentralization and Transfer Dependency. IMF Working Papers, 14(64), 1. https://doi.org/10.5089/9781484 354711.001

Hartono, D., \& Irawan, T. (2011). Decentralization policy and equality: A Theil analysis of Indonesian income inequality. European Journal of Economics, Finance and Administrative Sciences, 29, 41-51.

Jeffrey G . Williamson. (1965). Regional Inequality and the Process of National Development: A Description of the Patterns. Economic Development and Cultural Change, 13(4), 1-84. 
Lessmann, C. (2009). Fiscal decentralization and regional disparity: Evidence from crosssection and panel data. Environment and Planning A, 41(10), 2455-2473. https://doi.org/10.1068/a41296

Liu, Y., Martinez-Vazquez, J., \& Wu, A. M. (2017). Fiscal decentralization, equalization, and intra-provincial inequality in China. International Tax and Public Finance, 24(2), 248-281. https://doi.org/10.1007/s10797016-9416-1

Qiao, B., Martinez-Vazquez, J., \& $\mathrm{Xu}, \mathrm{Y}$. (2008). The tradeoff between growth and equity in decentralization policy: China's experience. Journal of Development Economics, 86(1), 112-128.

https://doi.org/10.1016/j.jdevec o.2007.05.002

Roodman, D. (2006). How to do xtabond2: An introduction to difference and system GMM in Stata. Stata Journal, 9(1), 86136.

https://doi.org/10.1177/1536867 x0900900106

Sepulveda, C. F., \& MartinezVazquez, J. (2011). The consequences of fiscal decentralization on poverty and income equality. Environment and Planning $C$ : Government and Policy, 29(2), 321-343. https://doi.org/10.1068/c1033r

Setiawan, F., \& Aritenang, A. F. (2019). The impact of fiscal decentralization on economic performance in Indonesia. IOP Conference Series: Earth and Environmental Science, 340(1). https://doi.org/10.1088/17551315/340/1/012021

Siburian, M. E. (2019). Fiscal decentralization and regional income inequality: evidence from Indonesia. Applied Economics Letters, 00(00), 1-4. https://doi.org/10.1080/1350485 1.2019.1683139

Siddique, M. A. B., Wibowo, H., \& $\mathrm{Wu}, \quad$ Y. (2008). Economics Fiscal Decentralisation and Inequality in Indonesia: 19992008. Discussion Paper 14.22, $1-33$.

Stossberg, S., \& Blöchliger, H. (2017). Fiscal Decentralisation and Income Inequality: Empirical Evidence from OECD Countries. Jahrbucher Fur Nationalokonomie Und Statistik, 237(3), 225-273. https://doi.org/10.1515/jbnst2017-1108 